\title{
Penerapan Metode Masase Tradisional "ESAM" terhadap Tingkat Kepuasan Pasien
}

\author{
Era Sapitra Alifiana Manjayati ${ }^{1}$, Nurkholis ${ }^{2}$, Fransisca Januarumi Marhaendra Wijaya ${ }^{3}$ \\ ${ }^{123}$ Pendidikan Olahraga Pascasarjana Universitas Negeri Surabaya \\ Email : $\underline{\text { era.19015@mhs.unesa.ac.id }}{ }^{1}$, nurkholisnurkholis@unesa.ac.id $^{2}$, \\ fransiscajanuarumi@unesa.ac.id ${ }^{3}$
}

\begin{abstract}
Traditional massage is a type of relaxation massage that has special characteristics of massage using hands or without using tools. The benefits of applying traditional massage to the body include relaxing muscles, reducing anxiety, restoring muscle function, and traditional medicine. ESAM traditional massage is a massage method developed in such a way by researchers to provide a different sensation from traditional massage methods in general. The purpose of this study was to determine how big the level of patient satisfaction with traditional "ESAM" massage. The research method used is Action Research which is descriptive analysis of the responses of 30 ESAM Beauty Care patients. On product quality indicators, 59.7\% answered satisfied, service quality indicators $53.7 \%$ answered satisfied, emotional quality indicators $62.3 \%$ answered satisfied, and price indicators $64 \%$ answered satisfied. The conclusion is that from 30 respondents the answers are dominated by satisfied and very satisfied answers
\end{abstract}

Keywords: traditional massage, massage method, patient satisfaction.

Abstrak. Masase tradisional merupakan salah satu jenis pijat relaksasi yang memiliki ciri khusus pemijatan dengan menggunakan tangan atau tanpa menggunakan alat bantu. Manfaat penerapan masase tradisional pada tubuh antara lain merelaksasi otot, menurunkan kegelisahan, mengembalikan fungsi gerak otot, dan pengobatan tradisional. Masase tradisional ESAM merupakan metode masase yang dikembangkan sedemikian rupa oleh peneliti untuk memberikan sensasi yang berbeda dari metode masase tradisional pada umumnya. Tujuan dari penelitian ini adalah untuk mengetahui seberapa besar tingkat kepuasan pasien terhadap masase tradisional "ESAM". Metode penelitian yang digunakan adalah Action Research yang bersifat deskriptif analisis dari hasil tanggapan 30 pasien ESAM Beauty Care. Pada indikator kualitas produk sebesar $59,7 \%$ menjawab puas, indikator kualitas pelayanan sebesar $53,7 \%$ menjawab puas, indikator kualitas emosional sebesar 62,3\% menjawab puas, dan indikator harga sebesar64\% menjawab puas. Kesimpulannya adalah dari 30 responden jawaban didominasi oleh jawaban puas dan sangat puas.

Kata Kunci: masase tradisional,metode masase, kepuasan pasien.

\section{PENDAHULUAN}

Masase merupakan keterampilan yang melibatkan unsur - unsur pengetahuan yang ilmiah, naluri, dan seni merawat tubuh.hal tersebut diperoleh melalui jalur pendidikan formal (bersertifikat) dan non formal (pengalaman). Seorang masseur atau pemijat laki - laki dan masseusatau pemijat perempuan haruslah memiliki pengalaman dan pengetahuan tentang masase, dikarenakan pada saat menangani pasien seorang terapis harus mampu mendiagnosa, memberikan solusi, dan mengeksekusi atau memberikan treatment.

Ilmu massase memiliki berbagai jenis, yaitu masase pengobatan (therapeutis massage), masase kecantikan (beauty or cosmetic massage), masase olahraga (sport massage), masase tradisional (traditional massage), hygine massage, masase relaksasi, masase aromaterapi, masase refleksi, dan masase oriental. Teknik memijat dalam masase disebut dengan manipulasi. Manipulasi masase terdiri dari memijat, menekan, memlurut, menggerus, mengguncang, memukul, dan lain - lain Reopajadi, Joesoef., dkk. (2014).

Salah satu jenis masase yang berkembang saat ini adalah masase tradisional atau yang biasa kita kenal dengan pijat tradisional. Banyak sekali masyarakat terutama di pedesaan yang memanfaatkan jenis masase atau pijat ini sebagai metode untuk pengobatan, seperti badan pegal linu, masuk angin, terkilir, dan lain - lain. Selain itu para terapis pijat tradisional ini atau sering disebut dengan istilah dukun pijat, 
menambahkan ramuan atau obat - obatan yang berasal dari tumbuhan yang ada disekitar. Kemampuan dan pengetahuan mereka diperoleh turuntemurun dari keluarga. Hal ini yang menjadi ciri khusus yang dimiliki oleh masase atau pijat tradisional.

Peneliti mengembangkan jenis masase tradisional ini dengan penambahan dan manipulasi yang disesuaikan kondisi di era modern ini. Dalam penelitian ini disebut dengan "Masase Tradisional ESAM". Masase Tradisional ESAM merupakan pengembangan dari masase tradisional dengan manipulasi serta urutan yang disesuaikan oleh kemampuan peneliti untuk memberikan sensasi berbeda dari masase tradisional pada umumnya, sehingga dapat diterima oleh masyarakat modern. Perbedaan yang terdapat pada masase tradisional ESAM dengan masase tradisional pada umumnya yang pertama adalah penggunaan minyak aromaterapi atau aromatherapy oil. Prasadja (2009) mengatakan bahwa aromaterapi merupakan salah satu terapi nonfarmakologis yang dapat mengatasi masalah insomnia. Selain itu dalam Meylana (2015), Suranto mengatakan bahwa aromaterapi merupakan salah satu komplementer yang memiliki efek menenangkan untuk mengurangi kecemasan, insomnia, dan ketegangan.

Penggunaan minyak aromaterapi ini bertujuan untuk memberikan sensasi berbeda beda sesuai dengan pilihan aroma oleh pasien. Artinya pasien dapat memilih aroma yang disukai, sehinga dalam proses pelaksanaannya pasien merasa lebih nyaman. Selain itu dengan kelebihan ini masase tradisional ESAM dapat diterima oleh semua kalangan masyarakat, baik masyarakat di pedesaan atau perkotaan.

Perbedaan yang kedua adalah Teknik atau manipulasi pijatan. Dalam masase tradisional ESAM menggunakan banyak jenis manipulasi antara lain: menggosok, memijat, menggerus, menggoncang, memukul dan mengurut. Hal ini bertujuan untuk memberikan dampak fisiologis dan psikologis kepada pasien. Sehingga manfaat dari masase atau pijat tradisional menjadi lebih kompleks. Perbedaan yang ketiga adalah tahapan melakukan pemijatan. Pada masase tradisional ESAM dibagimenjadi 3 tahapan yaitu : tahapan awal (tengkurap), tahapan kedua (terlentang), dan tahapan ketiga (duduk). Hal seperti ini tidak terlihat dalam masase tradisional pada umumnya. Dimana yang sering terjadi adalah terapis melakukan pemijatan secara berurutan namun tidak teratur,dan berfokus pada area yang didiagnosis atau area keluhan pasien.

Perbedaan yang keempat adalah perlengkapan yang digunakan. Masase tradisional pada umumnya, seorang terapis atau dukun pijat hanya menggunakan beberapa perlengkapan saja, seperti kain jarik, selimut, atau kain sarung sebagai media penutup bagian tubuh pasien serta menggunakan minyak tradisional atau balsem. Sedangkan padamasase tradisional ESAM menggabungkan antara tradisional dan modern,contohnya seperti : baju batik, kain jarik, bathok kelapa, tensi meter, inflared, krim wajah, minyak aromaterapi, handuk kecil, tisu, kotak musik, dan semua dikemas dalam sebuah mini box yang memudahkan seorang terapis membawa segala perlengkapan, sehingga terkesan lebih rapi dan elegan.

Manfaat dari terapi masase tradisional ESAM memiiki banyak kebaikan dalam tubuh baik secara fisilogis (kulit, otot, dan syaraf) maupun psikologis (emosi, pola pikir, dan lainlain). Manfaat secara fisiologis contohnya adalah memperlancar sirkulasi darah dalam tubuh, merelaksasikan otot yang tegang, perawatan kulit, mengembalikan fungsi otot dan syaraf, serta menigkatkan sistem kekebalan tubuh. Menurut Graha, Ali S. (2008) Masase sangat bermanfaat untuk merawat kulitdan mencegah penuaan, terlebih digabungkan dengan pemberian vitamin $\mathrm{E}$ untuk mempercepat pemulihan otot.

Manfaat secara psikologis contohnya adalah meningkatkan rasa percaya diri, memperbaiki kesehatan mental, memberikan susasan emosional yang positif, menambak kualitas tidur. Penelitian oleh Yuliana, N., Fauzi, Muhammad. \& Hastuti, S. (2019: 87) mengatakan bahwa tindakan masase atomaterapi lavender dapat menjadi masukan yang posiif dalam mengatasi keluhan insomnia pada lansia.

Dalam Prasetyo (2021: 2) Kotler mengemukakan bahwa kepuasan adalah perasaan senang atau kecewa seseorang yang muncul setelah membandingkan antara persepsi/ 
kesannya terhadap kinerja atau hasil suatu produkdan harapan - harapannya. Setiap konsumen memiliki selera masing - masing sehingga penyedia produk harus mampu menyesuaikan dengan kebutuhan dan harapan konsumen. Asmoro, D. \& Maftukhah,I. (2018: 77) mengatakan bahwa apabila seorang konsumen merasa puas, besar kemungkinan akan kembali untuk menggunakan jasa tersebut. Namun sebaliknya apabila merasa tidak puas, maka pasienakan enggan untuk kembali dan pasien akan membagikan cerita pengalamannya kepada orang lain yang dapat menurunkan tingkat kualitas produk.

Hasil penelitian terdahulu oleh Kristina, Dian (2014) mendapatkan hasil bahwa ada pengaruh antara kualitas produk terhadap kepuasan pelanggan. Hasil Penelitian lainnya oleh Anam, A., \& Kusnia, I. (2012) mengatakan bahwa pelayanan yang dilakukan tidak hanya kepada pasien melainkan juga pada keluarga pasien, sehingga semuanya merasakan kepuasan dan dapat meningkatkan kualitas RS DKT Mojokerto di mata masyarakat luas.

Melihat perkembangan jasa masase yang ada di masyarakat, tentunya kualitas masase perlu ditingkatkan dan dievaluasi. Oleh karena itu peneliti melakukan penelitian ini untuk mengetahui tingkat kepuasan pasien ESAM Beauty Care for Women Massag sehingga hasilnya dapat dijadikan bahan referensi pelaksanaan treatment dan perkembangan usaha jasa masase.

\section{METODE}

Jenis penelitian yang digunakan adalah penelitian kuantitatif yang bersifat deskriptif analisis untuk menggambarkan respon dari pasien. Desain penelitian ini menggunakan desain non eksperimen korelasional. Penelitian ini dilakukan di rumah pasien ESAM Beauty Care for Women Massage sejumlah 30 pasien yang terdiri dari pelajar, mahasiswa dan ibu rumah tangga. Penelitian ini dilaksanakan pada bulan April sampai dengan bulan Mei tahun 2021. Instrumen pengambilan data menggunakan kuisioner. Terdapat 4 indikator, yaitu kualitas produk, kualitas pelayanan, kualitas emosional,dan harga (Lupiyoadi, 2001 : 158). Dari ke empat indikator tersebut terdiri dari
35 pernyataan. Analisis data yang digunakan adalah descriptive analysis. Teknik analisis data bertujuan untuk mengetahui seberapa besar tingkat kepuasan pasien. Data dati hasil skor kuisioner diolah menggunakan aplikasi SPSS.

\section{HASIL DAN PEMBAHASAN}

Hasil penelitian ini diperoleh dari pemberian nilai pada jawaban kuisioner dengan berdasar skala likert. Dimana jawaban sangat tidak puas bernilai 1 , tidak puas bernilai 2 , tidak berpendapat bernilai 3 , puas bernilai 4 , dan sangat puas bernilai 5. Kemudian dijumlahkan untuk menentukan rata-rata jawaban masingmasing indikator keberhasilan. Hasilnya sebagai berikut :

Tabel 1. Prosentase rata-rata jawaban

\begin{tabular}{|c|c|c|c|c|}
\hline $\begin{array}{c}\text { Skala } \\
\text { Likert }\end{array}$ & $\begin{array}{c}\text { Kualitas } \\
\text { Produk }\end{array}$ & $\begin{array}{c}\text { Kualitas } \\
\text { Pelayanan }\end{array}$ & $\begin{array}{c}\text { Kualitas } \\
\text { Emosional }\end{array}$ & Harga \\
\hline STP & $0 \%$ & $0,3 \%$ & $0 \%$ & $0 \%$ \\
\hline TP & $1 \%$ & $2,3 \%$ & $0 \%$ & $0 \%$ \\
\hline TB & $4 \%$ & $6 \%$ & $4 \%$ & $3,3 \%$ \\
\hline P & $59 \%$ & $53,7 \%$ & $62,3 \%$ & $64 \%$ \\
\hline SP & $35,3 \%$ & $37,7 \%$ & $33,7 \%$ & $32,7 \%$ \\
\hline Total & $100 \%$ & $100 \%$ & $100 \%$ & $100 \%$ \\
\hline
\end{tabular}

Pada tabel diatas menunjukkan bahwa seluruh indikator rata - rata jawaban responden tertinggi pada jawaban puas. Dimana lebih dari $50 \%$ responden menjawab puas. Indikator kualitas produk mendapatkan rata - rata jawaban sangat tidak puas sebesar $0 \%$, tidak puas $1 \%$, tidak berpendapat $4 \%$, puas sebesar $59,7 \%$, dan sangat puas sebesar $35,3 \%$. Indikator kualitas pelayanan mendapatkan rata - rata jawaban sangat tidak puas sebesar $0,3 \%$, tidak setuju $2,3 \%$, tidak berpendapat $6 \%$, puas sebesar $53,7 \%$, dan sangat puas sebesar $37,7 \%$. Indikator kualitas emosional mendapatkan ratarata jawaban sangat tidak puas sebesar $0 \%$, tidak puas $0 \%$, tidak berpendapat $4 \%$, puas sebesar 52,3\%, dan sangat puas sebesar 33,7\%. Indikator harga mendapatkan rata - rata jawaban sangat tidak puas sebesar 0\%, tidak puas $0 \%$, tidak berpendapat $3,3 \%$, puas sebesar $64 \%$, dan sangat puas sebesar $32,7 \%$.

Kualitas produk masase tradisional "ESAM" mendapatkan respon positif dari responden dengan dibuktikan jawaban terbanyak pada opsi puas dan diikuti oleh jawaban sangat puas. Dilihat dari hasil rata rata jawaban responden dapat dikatakan bahwa 
pasien merasa puas dengan kualitas produk jasa masase tradisional "ESAM". Kotler \& Armstrong ( 2012: 283) mengemukakan kualitas produk adalah "the ability of a product to perform it's functions, it includes the product's overall durability, reability, precision, ease of operation and repair, and other valued attributes" yang artinya kemampuan sebuah produk untuk menunjukkan fungsinya, termasuk keseluruhan durabilitas, reabilitas, ketepatan, kemudahan penggunaan dan perawatan, dan nilai kelengkapan lainnya.

Ketika kualitas produk suatu barang atau jasa itu diniali baik oleh konsumen, maka besar kemungkinan konsumen akan kembali untuk membeli atau menggunakan jasa tersebut. Dalam penelitian ini kualitas produk dari masase tradisional "ESAM" mendapatkan respon yang positif, artinya pasien merasakan kepuasan terhadap jasa ini. Dengan adanya tanggapan positif ini, dapat menjadikan usaha jasa masase ini menigkat dan berkembang. Artinya kualitas produk sangatlah penting dalam peningkatan sebuah produksi barang atau penyedia jasa. Hal ini juga sesuai dengan hasil penelitian oleh Saidani, B., \& Arifin, S. (2012) bahwa secara empiris kualitas produk berpengaruh terhadap minat konsumen untuk membeli ulang.

Kualitas pelayanan mendapatkan rata rata jawaban sangat puas paling tinggi diantara indikator yang lainnya, walaupun dalam jawaban puas paling rendah dibandingkan indikator yang lainnya, hal ini membuktikan bahwa responden puas terhadap kualitas pelayanan masase tradisional ESAM. Pengalaman seorang terapis sangatlah diperlukan dalam menjalankan usaha jasa masase. Pengalaman akan membawa kualitas pelayanan kepada pasien terasa lebih profesional, sehingga menjadikan pasien semakin yakin dengan kompetensi yang dimiliki oleh terapis tersebut.

Kemampuan berkomunikasi, ketelitian, serta disiplin menjadi beberapa faktor yang menggambarkan kualitas pelayanan. Apabila pada saat perlakuan, seorang terapis mampu mendiagnosa, memberikan solusi dan mengeksekusi dengan baik, maka pasien pun akan semakin yakin terhadap pelayanannya.
Pelayanan yang baik akan berpengaruh besar terhadap kepuasan pasien, dimana dampaknya akan menciptakan keuntungan baik dari segi pemasukan atau pun jumlah pelanggan. Semakin baik kualitas pelayanan maka akan semakin tinggi tingkat kepuasan pasien (Panjaitan, J. E., \& Yuiati, A., 2016). Hal ini juga dikuatkan dengan hasil penelitian oleh Handoko (2017) yang menyatakan bahwa terdapat pengaruh yang signifikan antara kualitas pelayanan terhadap kepuasan konsumen dengan besaran sebesar 63,3\%.

Kualitas emosional pasien merupakan perasaan bahagia atau kecewa seseorang yang merupakan kemampuan seseorang untuk menilai, nenerima, mengelola, serta mengontrol emosi yang mengacu pada sebuah harapan positif. Efendi (2005: 177) mengungkapkan bahwa terdapat enam jenis emosi dasar yang dapat dijadikan indikator pengukuran emosional. Indikator tersebut antara lain : marah (anger),takut (fear), kejutan (surprise), jengkel (disgust), kebahagiaan (happiness), dan kesedihan (sadness).

Ketika pasien merasakan kenyamanan pada saat perlakuan sehingga harapannya terpenuhi, maka disitulah emosional positif dari pasien muncul. Begitu sebaliknya, apabila yang dirasakan tidak sesuai dengan yang diharapkan maka perasaan negatif akan muncul. hasil penelitian menunjukkan bahwa kualitas emosional pasien Sangat baik, dengan tidak adanya responden yang menjawab sangat tidak puas dan tidak puas. Lebih dari $60 \%$ responden menjawab puas dan lebiih dari 30\% lainnya menjawab sangat puas. Artinya $90 \%$ menjawab dengan tanggapan positif, yang dapa disimpulkan responden puas.

Hasil penelitian ini juga didukung dengan beberapa penelitain terdahulu, salah satunya adalah penelitian yang dilakukan oleh Kusuma (2015: 14) bahwa semakin positif emosional para tamu maka semakin nyaman pula jiwa dan pemikiran para tamu/ pelanggan untuk menginap di perusahaan tersebut. Hal tersebut juga sependapat dengan teori yang di kemukakan oleh Irawan dalam Oktaviani (2014:142) bahwa faktoremosional merupakan faktor yang sangat penting dalam mempengaruhi kepuasan. Emosional berasal 
dari perasaan atau emosi yang ditimbukan setelah mengkonsumsi suatu produk atau layanan tertentu (Ridwan \& Palupiningdyah, 2014:1).

Indikator harga dalam penelitian ini mendapatkan respon jawaban puas yang paling banyak dari tiga indikator lainnya. Serta tidak ada responden yang menjawab tidak puas maupun sangat puas. Artinya responden merasakan kepuasan terhadap harga yang ditentukan oleh peneliti. Pada pernyataan kedua yang berbunyi "adanya tarif paket hemat" mendapatkan respon tertinggi yaitu sebesar $70 \%$ responden menjawab puas. Melihat hal ini berarti pelanggan akan lebih tertarik apabila jasa masase tradisional ESAM memiliki kelebihan adanya tarif paket hemat.

Menurut Ghofur (2019: 39) Harga adalah indikator yang dijadikan konsumen sebagai tolak ukur antara manfaat yang dirasakan dengan harga suatu jasa atau barang. Apabila penentuan harga tidak sesuai dengan manfaat atau tidak sesuai harapan konsumen, maka tingkat kepuasan pasien akan menurun. Sebaliknya, apabila harga yang ditentukan memberkan kualitas, manfaat serta harapan kosumen terpenuhi, maka tingkat kepuasan konsumen akan meningkat. Terlebih apabila sebuah barang memiliki harga yang murah namun memberikan manfaat yang besar.

Harga yang ditentukan oleh peneliti sebesar Rp. 65.000,00 belum termasuk biaya tambahan transportasi apabila jarak rumah pasien lebih dari $5 \mathrm{~km}$. Pada kuisioner tentang nominal harga, nilai yang ditentukan diatas mendapatkan tanggapan jawaban sangat puas yang terbanyak dari pada 4 pernyataan lainnya pada indikator harga. Artinya dengan harga yang tertera pasien merasakan kepuasan sesuai dengan yang diharapkan.

Harga yang stabil, namun akan meningkat seiring peningkatan kualitas dan fasilitas akan membantu mempertahankan keingingan konsumen untuk berlangganan kembali. Namun apabila harga tidak stabil, konsumen akan ragu - ragu untuk kembali menggunakan jasa atau produk tersebut. Hal ini sesuai dengan hasil penelitian oleh Anwar, I., \& Satrio, B (2015: 14) bahwa harga berpengaruh signifikan dan negatif terhadap keputusan pembelian, artinya semakin harga naik maka keputusan untuk membeli semakin berkurang. Sebaliknya apabila harga turun maka keputusan membeli semakin bertambah.

\section{KESIMPULAN}

Besar prosentasi tingkat kepuasan pasien ESAM Beauty Care for Women Massage dengan melihat rata - rata hasil dari empat indikator penentu tingkat kepuasan, dengan rincian sebagai berikut : sangat tidak puas sebesar $0,1 \%$, tidak puas sebesar $0,8 \%$, tidak berpendapat sebesar $4,3 \%$, puas sebesar $59,9 \%$, sangat puas sebesar $34,8 \%$.

\section{SARAN}

Disarankan untuk melakukan persiapan yang lebih matang, baik itu dalam hal teknis maupun non teknis. Dalam penelitian selanjutnya dapat dilakukan pengisian angket sebelum dan sesudah terapi masase tradisional "ESAM". Dan juga perlu dikembangkan lagi penelitian yang sejenis, sehingga produk masase tradisional "ESAM" dapat dimasalkan kemasyarakat luas.

\section{DAFTAR PUSTAKA}

Anam, A., \& Khusnia, I. (2014). Tingkat Kepuasan Pasien Rawat Inap Dan Keluarga Pada Pelayanan Keperawatan Di Rumah Sakit DKT Mojokerto. Jurnal Imiah Kesehatan Politeknik Kesehatan Majapahit.4(2), 60 - 80.

Anwar, I. \& Satrio, B. (2015). Pengaruh Harga

Dan Kualitas Produk Terhadap Keputusan Pembelian. Jurnal Ilmu dan Riset Manajemen (JIRM). 4(12), 1 - 15. Asmoro, D., \& Maftukhah, I. (2018). Pengaruh Kualitas Layanan, Citra Merk dan Inovasi Layanan terhadap Kepuasan Pasien Rawat Inap pada RS Keluarga Sehat di Kab Pati. Management Analysis Journal, 6(1), 76-82. https://doi.org/10.15294/maj.v6i1.1596 0 .

Efendi, A. (2005). Revolusi Kecerdasan Abad 21. Bandung: Alfabeta. Gofur, A. (2019). Pengaruh Kualitas Pelayanan Dan Harga Terhadap Kepuasan Pelanggan. Jurnal Riset Manajemen Dan Bisnis (JRMB) Fakultas 
Ekonomi UNIAT, $\quad 4(1), \quad 37$

44.

https://doi.org/10.36226/jrmb.v4i1.240

Graha, Ali S. (2008). Manfaat Masase Wajah dan Vitamin E Pada Atlet. MEDIKORA Jurmal Ilmiah

Kesehatan Olahraga.

4(1), 123-149.

https://doi.org/10.21831/medikora.v0i1. 4705.

Handoko, Bagus. (2017). Pengaruh Promosi, Harga, Dan Kualitas Pelayanan Terhadap Kepuasan Konsumen Pada Titipan Kilat JNE Medan. Jurnal Ilmiah Manajemen \& Bisnis. 18(1), 61

http://dx.doi.org/10.30596\%2Fjimb.v18 i1.1098.

Kotler, P., \& Amstrong, G. (2012). Principles of Marketing. New Jersey : Pearson Education Limited.

Kristina, Dian. (2014). Pengaruh Kualitas Produk Terhadap Kepuasan Pelanggan Di Rumah Makan "Lesehan 88" Madiun. Jurnal Ilmiah Ekonomi dan Pembelajarannya. 2(1), 1 - 14. https://doi.org/10.25273/equilibrium.v2 i1.612.

Kusuma, R.,W. (2015). Pengaruh Kualitas Produk, Harga, Dan Emosional Terhadap Kepuasan Pelanggan. Jurnal Ilmu dan Riset Manajemen. 4(12), 1 17.

Lupiyoadi, Rambat.(2001). Manajemen Jasa, Teori, dan Praktik, edisi pertama. Jakarta: Salemba Empat.

Maksum, A. (2018). Metodologi Penelitian dalam Olahraga. Surabaya: Unesa Univesity Press.

Meylana, N. (2015). Efektivitas Akupresure dan Aromaterapi Lavender Terhadap Insomnia Pada Wanita Perimenopause di Desa Pancuranmas Magelang. Journal of Holistic Nursing Science. 2(2), 28-37.

Oktaviani, W. (2014). Pengaruh Kualitas Layanan, Emosional Pelanggan, dan Kemudahan Terhadap Loyalitas Melalui Kepuasan Pelanggan. Jurnal Ilmu Manajemen. 2(1), 140 - 152.
Panjaitan, E. A., \& Yuliati, A. (2016). Pengaruh Kualitas Pelayanan Terhadap Kepuasan Pelanggan Pada JNE Cabang Bandung. DeReMa Jurmal Manajemen. 11(2), 265 - 289. https://dx.doi.org/10.19166/derema.v11 i2.197.

Prasadja, A. (2009). Ayo Bangun Dengan Bugar Karena Tidur Yang Benar. Jakarta: Penerbit Hikmah

Prasetio, A. (2012). Pengaruh Kualitas Pelayanan Dan Harga Terhadap Kepuasan Pelanggan. Management Analysis Journal, 1(1). https://doi.org/10.15294/maj.v1i1.497.

Ridwan, M. \& Palupiningdyah. (2014). Pengaruh Nilai Emosional, Nilai Sosial, dan Nilai Kualitas Terhadap Kepuasan Pelanggan Manajemen. Analisys Journal. 3(1), $1-6$.

Roepajadi, Joesoef., dkk. (2014). Masase Olahraga. Surabaya: Unesa University Press.

Saidani, B., \& Arifin, S. (2012). Pengaruh Kualitas Produk Dan Kualitas Layanan Terhadap Kepuasan Konsumen Dan Minat Beli Pada Ranch Market. JRMSI Jurnal Riset Manajemen Sains Indonesia, 3(1), 1-22.

Yuliana,N., Fauzi,M., \& Hastuti, S. (2019). Pengaruh Masase Aromaterapi Lavender Terhadap Penurunan Tingkat Insomnia Pada Lansia Di Balai Sosial Lanjut Usia Mandalika Mataram. Jurnal Riset Kajian Teknologi Dan Lingkungan, 2(2), 84-88. Retrieved from http://ejournallppmunsa.ac.id/index.php/jrktl/art icle/view/73 